Egyptian Journal of Aquatic Biology \& Fisheries

Zoology Department, Faculty of Science,

Ain Shams University, Cairo, Egypt.

ISSN $1110-6131$

Vol. 25(3): 13 - 21 (2021)

www.ejabf.journals.ekb.eg

\title{
The Effect of Titanium Dioxide Nanoparticles Against Cyanobacterial Microorganisms
}

\author{
Karima Boutarfa $^{1,2^{*}}$, Amal Saoudi ${ }^{1}$, Khedidja Boufligha ${ }^{1}$, Houneida Benbouzid ${ }^{3}$, \\ Racha Mihoub $^{2}$, Mourad Bensouilah ${ }^{1}$ \\ ${ }^{1-}$ Ecobiology Laboratory for Marine Environments and Costal Areas, Marine Sciencs Departement, Badji \\ Mokhtar-Annaba University, 23000 ALGERIA. \\ 2- Biochimestry and Applied Microbiology Laboratory, Biochimestry Department, Faculty of sciences, \\ Badji Mokhtar- Annaba University, 23000 ALGERIA. \\ 3- Cellular Toxicology Laboratory, Biology Departement, Faculty of sciences, Badji Mokhtar- Annaba \\ University, 23000 ALGERIA.
}

*Corresponding Author: karima.biob@yahoo.fr

\section{ARTICLE INFO \\ Article History: \\ Received: March 18, 2021 \\ Accepted: April 18, 2021 \\ Online: May 25, 2021}

Keywords:

Antibacterial effect,

Titanium dioxide,

nanoparticles $\left(\mathrm{TiO}_{2} \mathrm{NPs}\right)$,

Cyanobacteria,

Microcystis sp.,

Health risks.

\begin{abstract}
Titanium dioxide nanoparticles $\left(\mathrm{TiO}_{2} \mathrm{NPs}\right)$ present a high interest as an excellent antibacterial agent against pathogenic microorganisms. Currently, the massive proliferation of potentially toxic cyanobacteria in the water of dams presents a threat to the public health of these water consumers. This study was maintained to evaluate the antibacterial activity of $\mathrm{TiO}_{2}$ NPs against the cyanobacteria «Microcystis sp.» responsible for toxic blooms in the freshwater reservoirs intended for drinking water production. Three concentrations of $\mathrm{TiO}_{2}$ NPs (150 mg. $\mathrm{l}^{-1}, 300 \mathrm{mg} . \mathrm{l}^{-1}$ and $\left.600 \mathrm{mg} . \mathrm{l}^{-1}\right)$ were tested in the laboratory on two strains of Microcystis sp. (S1, S2) over a period of eight days. In parallel, three biotic variables were measured:Microcystis sp. cells density (cell.ml $\left.{ }^{-1}\right)$, Chlorophyll (a) $\left(\mu \mathrm{g} .1^{-1}\right)$, and Phycocyanin $\left(\mu \mathrm{g} .1^{-1}\right)$ content every 48 hours all along the experimental period. A remarkable decrease in cell densities

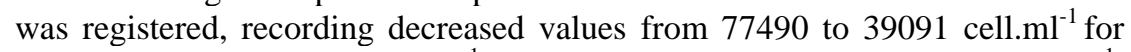
$\mathrm{S} 1$ and from 2801 to 0 cell. $\mathrm{ml}^{-1}$ for S2 with the concentration of $600 \mathrm{mg} \cdot \mathrm{l}^{-1}$. Additionally, the chlorophyll (a) content fell from 45 to $8 \mu \mathrm{g} \cdot \mathrm{l}^{-1}$ for $\mathrm{S} 1$, and from 34 to $0 \mu \mathrm{g} . l^{-1}$ for S2. Similarly, treatment with $\mathrm{TiO}_{2} \mathrm{NPs}$ caused the degradation of phycocyanin from 200 to $65 \mu \mathrm{g} .1^{-1}$ for S1 and from 200 to $0 \mu \mathrm{g} .1^{-}$ ${ }^{1}$ for S2 with the highest concentration of these nanoparticles $\left(600 \mathrm{mg} . \mathrm{l}^{-1}\right)$. $\mathrm{TiO}_{2}$ NPs exhibit a very important antibacterial effect against Microcystis. sp. Thus, $\mathrm{TiO}_{2}$ NPs can be used in the future to reduce the high biomasses of cyanobacteria during the process of tap water production.
\end{abstract}

\section{INTRODUCTION}

The innovative nanotechnology applications and their nanomaterials are primarily used in biomedical, environmental and electronic fields. The group of metal oxides nanoparticles is the largest group of nanomaterials that received a significant attention being, hence, applied in a plenty of products. 
Obeizi et al. (2020) and Obeizi et al. (2021) confirmed that, several metal oxides might show bacteriostatic or bactericidal effect.This antibacterial activity differs according to the type and number of the tested bacteria, depending on the physicochemical properties, the concentration and the experimental conditions of the used nano-molecules (Vojislav et al., 2020).

Titanium dioxide nanoparticles $\left(\mathrm{TiO}_{2} \mathrm{NPs}\right)$ are among the most globally produced nanomaterials (Piccinno et al., 2012) due to their high refractive index and resistance to discolouration, especially to stability, photocatalytic, depolluting and antibacterial properties. Kahru and Dubourguier (2010) classified those NPs as harmful to many water organisms such as crustaceans and nematodes. Moreover, they may harm microorganisms as yeast, micro-algae and bacteria. Considerably, NPs are used as catalyst for water purification (Botelho et al., 2014; Janer et al., 2014) and as an antimicrobial agent as well (Benbouzid et al., 2019).

On the other hand, the increasing cyanobacterial bloom occurrences around the world has introduced a considerable research subject for scientists (Merel et al., 2013) to identify the responsible factors for their proliferation. Additionally, this may draw scientist to think carefuly and place in action an arranged and well structured surveillance system that can prevent and reduce the cyanobacterial bloom occurrence. Such a concern is due to the toxicological risks of those microorganisms and the impact of which that uncontrolled cyanobacterial blooms may have on aquatic ecosystems (Carman \& Tomevska, 2019).

It is worth mentioning that, the cyanobacteria degrade water quality (Fleming $\boldsymbol{e t}$ al., 2002) and produce several cyanotoxins as neurotoxins, hepatotoxins, and dermatotoxins that can affect both animals and humans (Lance et al., 2010a, b; Carmichael \& Boyer, 2016 ; Metcalf et al., 2020). In this context, the frequent consumption and/or the exposure to the contaminated drinking water or aquatic foods can lead to a serious threat to public health safety (Agasild $\boldsymbol{e t}$ al., 2019).

Consequently, the main aim of this study was to evaluate the antibacterial effect of $\mathrm{TiO}_{2}$ NPs on a potentially toxic cyanobacteria on basis of the probability of using those NPs in water treatment processes in the future. The present test was achieved via the exposure of two freshwater strains Microcystis sp. on an increasing concentrations of $\mathrm{TiO}_{2}$ NPs suspension, where three biotic parameters were measured (Microcystis sp. cells density (cell.ml $\left.l^{-1}\right)$, Chlorophyll (a) $\left(\mu \mathrm{g} . \mathrm{l}^{-1}\right)$ and Phycocyanin $\left(\mu \mathrm{g} . \mathrm{l}^{-1}\right)$ contents) in a period of eight days.

\section{MATERIALS AND METHODS}

\section{The preparation of $\mathrm{TiO}_{2} \mathrm{NPs}$ suspension}

Three concentrations of $\mathrm{TiO}_{2}$ NPs $\left(150 \mathrm{mg} . \mathrm{l}^{-1}, 300 \mathrm{mg} \cdot \mathrm{l}^{-1}\right.$ and $\left.600 \mathrm{mg} \cdot \mathrm{l}^{-1}\right)$ were prepared in BG11 medium (particules were kindly donated by the Surfaces and Solids 
Interfaces Laboratory Badji mokhtar-Annaba University), then the solutions were sonicated with pulsatile movements for $5 \mathrm{~min}$ to insure the dispersion of the nanomolecules.

\section{Cyanobacteria culture and cells growth testing}

The growth of cyanobacterial cells culture was maintained in BG11 medium, $\mathrm{pH}=$ 7 at $25{ }^{\circ} \mathrm{C}$ with a photoperiodic cycle of $12 \mathrm{~h}: 12 \mathrm{~h}$ light and dark. Each culture contained $1 \mathrm{~g}$ of Microcystis sp. cells (Microcystis sp. strains were collected from Algerian freshwaters in 2019) then the prepared concentrations were added (150 mg. $\mathrm{l}^{-1}, 300 \mathrm{mg} . \mathrm{l}^{-1}$ and $600 \mathrm{mg} . \mathrm{l}^{-1}$ of $\mathrm{TiO}_{2} \mathrm{NPs}$ ) to the Microcystis sp. Cultures. A frequent agitation was realized to avoid precipitation of any cell or molecule in the flasks. Each prepared serie contained a control sample without NPs. The experience extended for eight days successively.

Cells densities was counted with "Nageotte" counting cell using a Carl Zeiss model (Axiostar plus) microscope equipped with digital uEye32 camera and according to the technique of Brient $\boldsymbol{e t}$ al. (2001). The aforementioned work was achieved beginning from day 0 , every 48 hours all along the experiment. To minimize error, the counting operation was performed in triplicate. The cell densities were expressed in (cells. $\left.\mathrm{ml}^{-1}\right)$

\section{Photosynthetic pigments measurement}

The chlorophyll (a) (Chl a) pigments were measured using chlorophyll TRIOS MicroFlu-Chl probe; which uses a fluorimeter equipped with a blue diode.The excitation wave length filter is at $470 \mathrm{~nm}$ and the emission is at $685 \mathrm{~nm}$, with a range from 0 to 100 $\mu \mathrm{g} . \mathrm{l}^{-1}$ and a sensitivity $=0.1 \mu \mathrm{g} . \mathrm{l}^{-1}$. The results were expressed in $\mu \mathrm{g} . \mathrm{l}^{-1}$.

Phycocyanin (PC) pigments (pigment characteristic of cyanobacteria) measurement was carried out using a sensitive and high selective probe (TRIOS MicroFlu-blue phycocyanin) which uses a fluorimeter, submersible and miniaturized (diameter of 48 $\mathrm{mm}$ and $200 \mathrm{~mm}$ length), equipped with an ultra-brightred LEDs, and provided with excitation wave length filter at $620 \mathrm{~nm}$ and emission at $655 \mathrm{~nm}$ with a band width of 10 $\mathrm{nm}$. This probe gives a linear response to phycocyanin concentration up to $200 \mu \mathrm{g} . \mathrm{l}^{-1}$ and a precision of $0.02 \mu \mathrm{g} . \mathrm{l}^{-1}$. The results were expressed in $\mu \mathrm{g} . \mathrm{l}^{-1}$.

\section{RESULTS}

\section{Microcystis sp. densities variation}

The contact between Microcystis sp. strains and the $\mathrm{TiO}_{2}$ NPs allowed a reduction

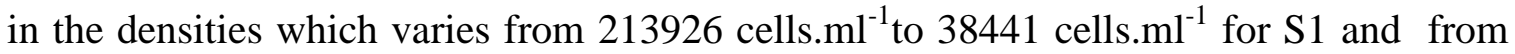
15959 cells.ml ${ }^{-1}$ to 0 cells. $\mathrm{ml}^{-1}$ for S2. Fig.(1) shows a decreasing variation in the function of $\mathrm{TiO}_{2} \mathrm{NPs}$ concentrations and the exposure time to those nanoparticules, with a remarkable reduction in $\mathrm{S} 2$ from the second day comparing to $\mathrm{S} 1$. The highest $\mathrm{TiO}_{2} \mathrm{NPs}$ concentration gave the highest rate of cell decrease of S1 after 8 days of contact, however, the $\mathrm{S} 2$ was eliminated by the $150 \mathrm{mg} \cdot \mathrm{l}^{-1}$ dose from the second day. Those results 
show that the $\mathrm{TiO}_{2}$ NPs exerts a good bactericidal activity against the two strains of Microcystis sp., and that the antibacterial activity is directly linked to the concentration of $\mathrm{TiO}_{2}$ and the contact time. Furthermore, it was noticed that the S2 was more sensitive than the $\mathrm{S} 1$.

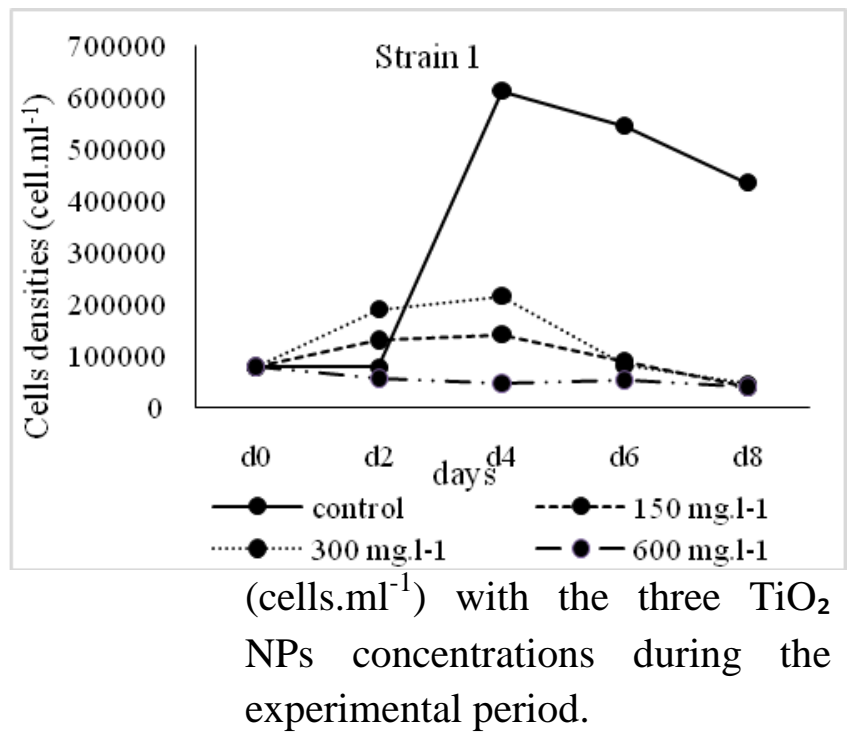

Fig. 1. Microcystis sp. cells density

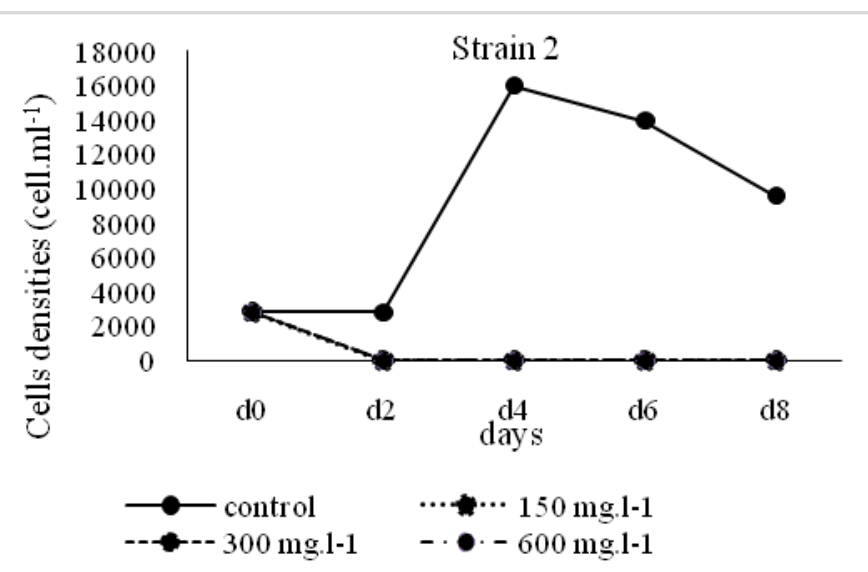

Fig.(2) shows a representative explanation for the damages that $\mathrm{TiO}_{2} \mathrm{NPs}$ caused to the cells of Microcystis sp. in particular, and to the colonies in general. The mucilageneuse membrane is deformed and the molecules of $\mathrm{TiO}_{2} \mathrm{NPs}$ are clearly covering the colonies.
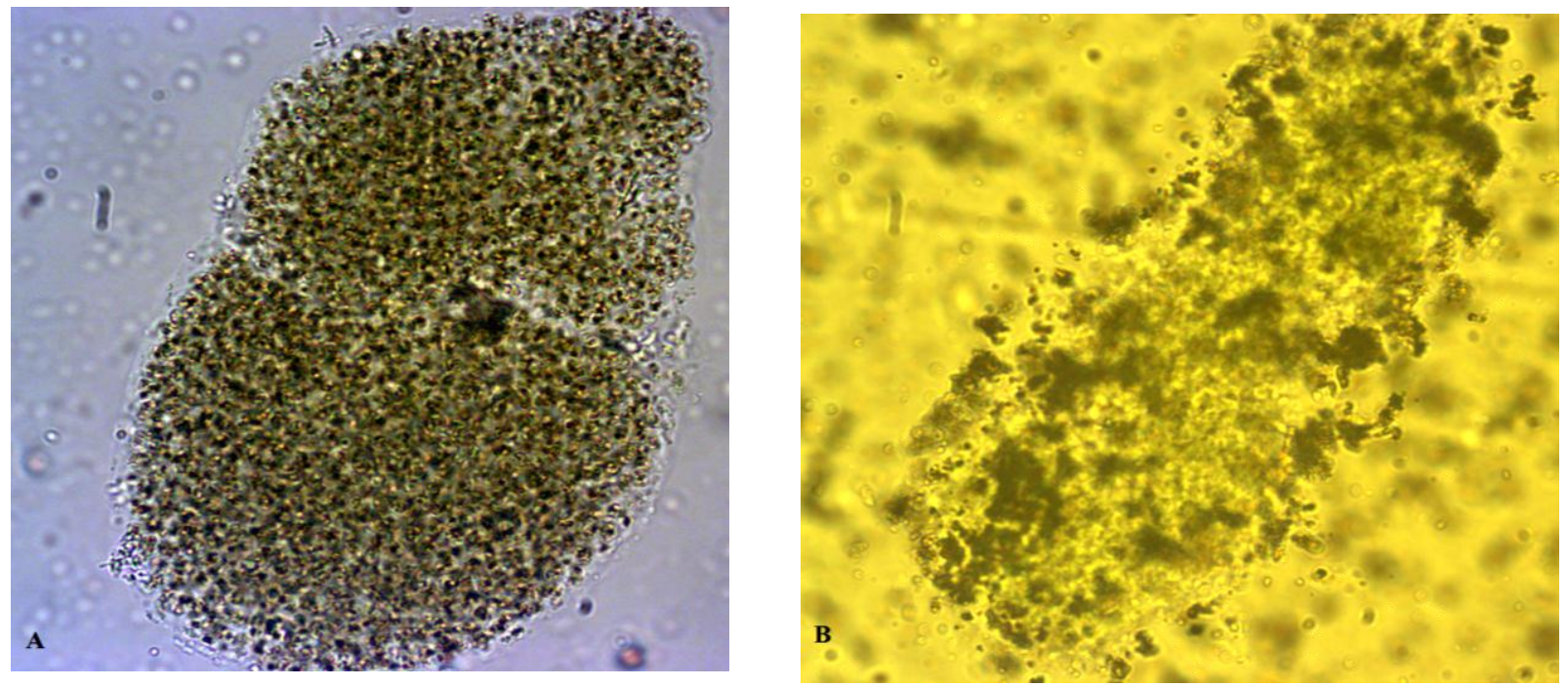

Fig. 2. Microcystis sp. colonies appariation under (Axiostar plus) microscope GRx400, A : Control solution, B : Presence of $\mathrm{TiO}_{2} \mathrm{NPs}$ (2019). 


\section{Photosynthetic pigments variation}

The results of the chlorophyll $(\mathrm{CHl})$ (a) and phycocyanin content in the two strains; S1 and S2, represented in Fig. (3 \& 4) show a decrease that is proportional to the three concentrations of $\mathrm{TiO}_{2}$ NPs and the contact time. The lowest content of the two pigments were observed in S1, with the concentration of $600 \mathrm{mg} . \mathrm{l}^{-1}$ after eight days of contact. However, the lowest values for S2 were observed with the concentration of $150 \mathrm{mg} . \mathrm{l}^{-1}$ beginning from the second day.The maximum concentration of $\mathrm{Chl}$ (a) content was registered with the $\mathrm{S} 1$ (45 $\mu \mathrm{g} . \mathrm{l}^{-1}$ ), however the minimum concentration was $0 \mu \mathrm{g} . \mathrm{l}^{-1}$ for the second one. Thus, the levels of PC varied from $200 \mu \mathrm{g} .1^{-1}$ to $65 \mu \mathrm{g} .1^{-1}$ for S1 while for the second strain, they ranged from $200 \mu \mathrm{g} \cdot \mathrm{l}^{-1}$ to $0 \mu \mathrm{g} \cdot \mathrm{l}^{-1}$.
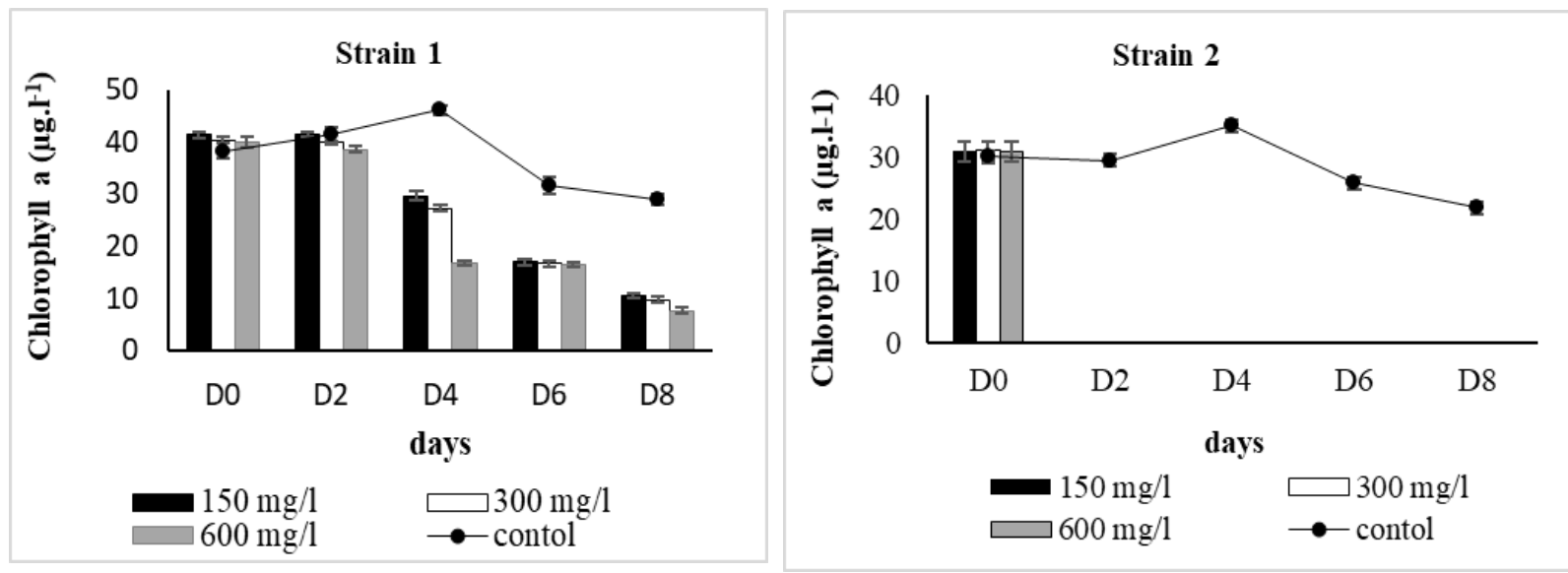

Fig. 3. Chlorophyll (a) concentrations $\left(\mu \mathrm{g} \cdot 1^{-1}\right)$ on the function of the $\mathrm{TiO}_{2} \mathrm{NPs}$ concentrations along the eight days.
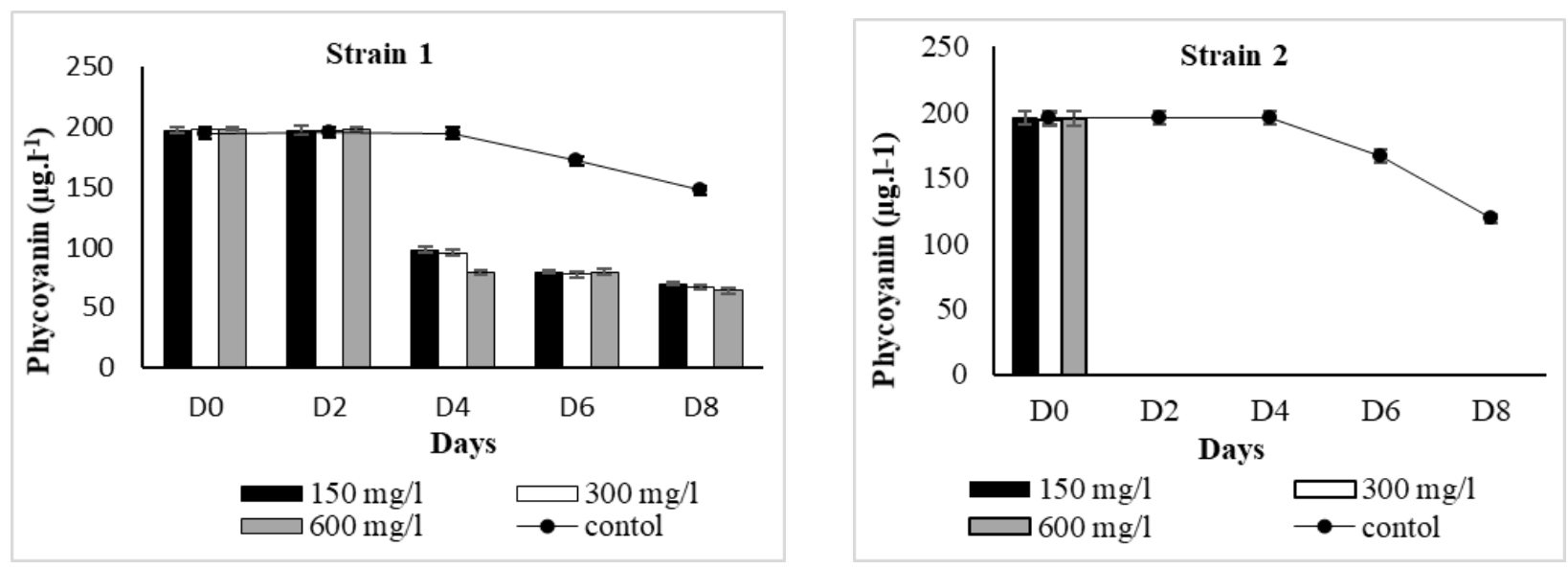

Fig. 4. Phycocyanin pigments concentration $\left(\mu \mathrm{g} .1^{-1}\right)$ on the function of the $\mathrm{TiO}_{2} \mathrm{NPs}$ concentrations along the eight days. 


\section{DISCUSSION}

The results relating to both of the cyanobacterial strains densities showed a proportional decrease with the tested concentrations of $\mathrm{TiO}_{2} \mathrm{NPs}$. The lowest densities were observed with the highest concentration $\left(600 \mathrm{mg} \cdot \mathrm{l}^{-1}\right)$. Microscopic examination allowed researchers to see the antibacterial effect of $\mathrm{TiO}_{2} \mathrm{NPs}$ on Microcystis sp. through the deformation in the morphology of cell walls and colonies, besides the presence of a large number of destroyed cells in the slide (Fig. 2).

The membrane of cyanobacteria is charged negatively, it is composed of peptidoglycan, glycopeptide and polysaccharide which offers many binding sites for $\mathrm{TiO}_{2}$ NPs since it is charged positively via non-specific interactions; hydrogen bonding, hydroliptic or electrostatic (Rai et al., 2009; Liu et al., 2018). Those bonds can perforate cells membrane and allow the accumulation of those nanoparticles inside the cell. The nanoparticules accumulation would, hence, generate oxidative stress (Tran et al., 2016; Hu et al., 2018). Consequently, the intensive presence of radical molecules $\left(\mathrm{OH}^{-}, \mathrm{O}_{2}^{-}\right)$ would cause non reversible damage that leads to cell death.

Rai et al. (2009) reported that the smallest nanoparticles have the strongest bactericidal effect. Thus, the antibacterial effect of $\mathrm{TiO}_{2}$ as a metal oxide nanoparticules on Microcystis sp. strains is probably due to the small size that allows their penetration inside the cell causing oxidative stress via over production of reactive oxygen species ROS ».

In addition, Miller $\boldsymbol{e t}$ al. (2012) reported that, the « ROS » high production is due to protein oxidation, unsaturated lipids or even nucleicacids, which can cause serious DNA damage and may lead to bacterial cell destruction. Noticeably, $\mathrm{TiO}_{2}$ dissolution to $\mathrm{Ti}^{+2}$ and $\mathrm{OH}^{-}$, in the presence of water and oxygen, can lead to the formation of a highly reactive hydroxyl radical which can react with 2-deoxyribose of DNA and generate a modified nucleic bases. The generated element is one of the predominant lesions generated by the hydroxyl radical in the body that corresponds to the 8-oxo-7,8dilydroguanine resulting from the oxidation of guanine by $\mathrm{TiO}_{2} \mathrm{NPs}$.

For the two photosynthetic pigments: the results of both Chlorophyll (a) and phycocyanin showed a decrease with the nano-concentrations, in a way that coincides with results of Liu et al. (2018) and Tran et al. (2016). Chl (a) reduction can be explained by the presence of the $\mathrm{O}_{2}^{-}$radical which destroys that pigment. Based on those parameters, it was found that, $\mathrm{TiO}_{2} \mathrm{NPs}$ exerted an antibacterial effect against Microcystis sp. with respect to the two strains S1 and S2. 


\section{CONCLUSION}

It can be concluded from the results of the present study that $\mathrm{TiO}_{2}$ NPs have an antibacterial effect on Microcystis sp. and that this effect is directly dependent on the concentrations of $\mathrm{TiO}_{2}$ NPs, the contact time with Microcystis sp. and susceptibility or resistance of the strains. Therefore, $\mathrm{TiO}_{2}$ NPs can be offered as an antibacterial agent against Microcystis sp.with doses that do not exceed $600 \mathrm{mg} . \mathrm{l}^{-1}$.

With a view to reduce health and economic risks associated with the presence of Microcystis sp. and its toxins (Microcystin LR) in the majority of blooms produced in drinking water production, further investment is recommended to know at which stage of water treatment it should be introduced. Nevertheless, the current study should be supplemented by eco-toxicological studies on $\mathrm{TiO}_{2} \mathrm{NPs}$ to prevent their approximate risks on environmental and public health.

\section{ACKNOWLEDGEMENTS}

This research did not receive any specific grant from funding agencies in the public, commercial, or not-for-profit sectors.

\section{REFERENCES}

Agasild, H.; Panksep, K.; Tonno, I.; Blank, K.; Koiv, T.; Freiberg, R.; Laugaste, R.; Jones, RI.; Noges, P. and Noges, T. (2019). Role of potentially toxic cyanobacteria in crustacean zooplankton diet in a eutrophic lake. Harmful Algae., 89: 101688.

Benbouzid, H.; Obeizi, Z. and Djahoudi, A.E.G. (2019). Antimicrobial Effects of $\mathrm{TiO}_{2}$ Nanoparticles against Drug-Resistant Bacteria and Candida albicans. IJIAAR., $3(2): 177-182$.

Botelho, M.C.; Costa, C.; Silva, S.; Costa, S.; Dhawan, A.; Oliveira, P.A. and Teixeira, J.P. (2014). Effects of titanium dioxide nanoparticles in human gastric epithelial cells in vitro. Biomed. Pharmacother., 68(1): 59-64.

Brient, L.; Vézie, C. and Bertru, G. (2001). Evaluation des efflorescences à cyanobactéries dans des eaux de cours d'eau et plans d'eau breton. Université de Rennes 1., 80pp.

Carman, R. and Tomevska, S. (2019). A Million Fish Dead in 'distressing' Outback Algal Bloom at Menindee.

Carmichael, W.W.; and Boyer, G.L. (2016). Health impacts from cyanobacteria harmful algae blooms: Implications for the North American Great Lakes. Harmful 
Algae., 54: 194-212.

Fleming, L.E.; Rivero, C.; Burns, J.; Williams, C.; Bean, J.A.; Shea, K.A. and Stinn, J. (2002). Blue green algal (cyanobacterial) toxins, surface drinking water, and liver cancer in Florida. Harmful Algae., 1(2): 157-168.

Hu, J.; Wang, J.; Liu, S.; Zhang, Z.; Zhang, H; Cai, X.; Pan, J. and Liu, J. (2018). Effect of $\mathrm{TiO}_{2}$ nanoparticule aggregation on marine microalgae isochrysis galbana. J. Environ.Sci., 66: 208-215.

Janer, G.; del Molino, E.M.; Fernández-Rosas, E.; Fernández, A. and VázquezCampos, S. (2014). Cell uptake and oral absorption of titanium dioxide nanoparticles. Toxicol Lett., 228(2): 103-110.

Kahru, A. and Dubourguier, H.C. (2010). From ecotoxicology to nanoecotoxicology. Toxicology., 269: 105-119.

Lance, E.; Josso, C.; Dietrich, D.; Ernst, B.; Paty, C.; Senger, F.; Bormans, M.; and Gerard, C. (2010)a. Histopathology and microcystin distribution in Lymnaea stagnalis (Gastropoda) following toxic cyanobacterial or dissolved microcystin-LR exposure. Aquat. Toxicol., 98: 211-220.

Lance, E.; Brient, L.; Carpentier, A.; Acou, A.; Marion, L.; Bormans, M.; and Gérard, C. (2010)b. Impact of toxiccyanobacteria on gastropods and microcystin accumulation in a eutrophiclake (Grand-Lieu, France) withspecialreference to Physa (= Physella) acuta. Sci. Total Environ., 408: 3560-3568.

Liu, J; Pinghe, Y. and Zhao, L. (2018). Adverse effect of nano- $\mathrm{TiO}_{2}$ on the marine macroalgae Gracilaria lemaneiformis (Gracilariales, Rhodophyta): growth and antioxidant activity. China RSC Adv., 8: 29172-29178.

Merel, S.; Walker, D.; Chicana, R.; Snyder, S.; Baures, S. and Thomas, O. (2013). State of knowledge and concerns on cyanobacteria blooms and cyanotoxins. Environ. Int., 59: 303-327.

Metcalf, J.S. and Codd, G.A. (2020). Co-Occurrence of Cyanobacteria and Cyanotoxins with Other Environmental Health Hazards : Impacts and Implications. Toxins., 12: 629.

Miller, R.J.; Bennett, S.; Keller, A.A.; Pease, S. and Lenihan, H.S. (2012). $\mathrm{TiO}_{2}$ nanoparticles are phototoxic to marine phytoplancton. PLoS One., 7(1): 30321.

Obeizi, Z.; Benbouzid, H.; Ouchenanec, S.; Yılmazd, D.; Culhad, M. and Bououdina, M. (2020). Biosynthesis of Zinc oxide nanoparticlesfrom essential oil of Eucalyptus globulus with antimicrobial and anti-biofilm activities. Mater. Today Commun., 25: 1-10. 
Obeizi, Z.; Benbouzid, H.; Bouarroudj, T.; Benzaid, C. and Djahoudi, A. (2021). Synthesis, characterization of (Ag-SnO2) nanoparticles and investigation of its antibacterial and anti-biofilm activities. J. New Technol. Mater., 10(2): 10-17

Piccinno, F.; Gottschalk, F.; Seeger, S. and Nowack, B. (2012). Industrial production quantities and uses of ten engineered nanomaterials in Europe and the world. J Nanopart Res., 14(9): 1-11.

Rai, M.; Yadav, A. and Gade, A. (2009). Silver nanoparticles as a new generation of antimicrobials. Biotechnol. Adv., 27: 76-83.

Tran, T.H.; Nguyen, T.K.; Nguyen, T.T.; Phuong, T.; Le, Thi P.; Do, V.; Trinh, Q.H. and Duong, T.T. (2016). Nanoparticles as a control for cyanobacterial bloom. J. Viet. Env., 8(3): 161-166.

Vojislav, S.; Sladjana, B. and Tanaskovi'c. (2020). Antibacterial activity of metal oxide nanoparticles. In: "Micro and Nano Technologies". Rajendran, S.; Mukherjee, A.; Nguyen, T.A.; Godugu, C.; Shukla. R.K. (Eds.). Nanotoxicity., pp.241-274. 